\title{
Corporate Governance and Capital Structure Decisions: Evidence from Chinese Listed Companies
}

\author{
Sunitha VIJAYAKUMARAN ${ }^{1}$, Ratnam VIJAYAKUMARAN ${ }^{2}$
}

Received: February 10, 2019 Revised: June 15, 2019 Accepted: July 1, 2019

\begin{abstract}
This study examines the impact of corporate governance on capital structure decisions based on a large panel of Chinese listed firms. Using the system Generalized Method of Moments (GMM) estimator to control for unobserved heterogeneity, endogeneity, and persistency in capital structure decisions, we document that the ownership structure plays a significant role in determining leverage ratios. More specially, we find that managerial ownership has a positive and significant impact on firms' leverage, consistent with the incentive alignment hypothesis. We also find that managerial ownership only affects the leverage decisions of private firms in the post-2005 split share reform period. State ownership negatively influence leverage decisions implying that SOEs may face fewer restrictions in equity issuance and may receive favourable treatments when applying for seasoned equity financing, thus use less debt. Furthermore, our results show that while foreign ownership negatively influences leverage decisions, legal person shareholding positively influences firms' leverage decisions only for state controlled firms. We also find that the board structure variables (board size and the proportion of independent directors) do not influence firms' capital structure decisions. Our findings suggest that recent ownership reforms have been successful in terms of providing incentive to managers through managerial shareholdings to take risky financial choices.
\end{abstract}

Keywords: Ownership Structure, Corporate Governance, Leverage, Ownership Reform, Emerging Markets, China.

JEL Classification Code: G30, G32, G38, G39, 016.

\section{Introduction}

In recent years, much of the attention of academics and practitioners has been focused on corporate governance issues, in particular, the impact of corporate governance issues on several important decisions (primarily investment and financing decisions) made by managers and the resultant performance and valuation of firms (See Shleifer \& Vishny, 1997; Brown, Beekes, \& Verhoeven, 2011; Wintoki, Linck \& Netter, 2012). Jensen and Meckling (1976) show that agency problem between managers and shareholders can be reduced by the use of debt capital as a governance

1 First Author. Senior Lecturer, Department of Commerce, Faculty of Management Studies and Commerce, University of Jaffna, Sri Lanka. Email: sunithav@univ.jfn.ac.lk

2 Corresponding Author. Senior Lecturer, Department of Financial Management, Faculty of Management Studies and Commerce, University of Jaffna [Postal Address: P.O Box 57, Thirunelvely, Jaffna 40000, Sri Lanka]. Email: vijayjfn@gmail.com

() Copyright: Korean Distribution Science Association (KODISA)
This is an Open Access article distributed under the terms of the Creative Commons Attribution NonCommercial License (https://creativecommons.org/licenses/by-nc/4.0/) which permits unrestricted noncommercial use, distribution, and reproduction in any medium, provided the original work is properly cited. mechanism. Since the use of debt financing prevents dilution of equity ownership of insiders and provides additional monitoring from the debt holders, it can increases firm value by reducing agency costs of equity. The subsequent theoretical development in the agency theory (Grossman \& Hart, 1982; Jensen 1986; Stulz, 1990), also confirm that leverage indeed can be an effective corporate governance mechanism that mitigates the agency problem between managers and shareholders by disciplining managers. The rationale behind this is threefold (1) managers are closely monitored by debt-holders and the financial market (Jensen \& Meckling, 1976; Rajan \& Winton, 1995; Stulz, 2000) (2) fixed interest payment to the debt holders disgorges the free cash flow available to the managers' discretionary spending (Jensen, 1986) and (3) potential for risk of bankruptcy and the resulting loss of reputation and jobs for managers (Fama, 1980; Grossman \& Hard, 1982; Williams, 1987). However, the crucial empirical question is how to encourage managers who consider leverage as constraining their discretionary power, to choose the optimal level of leverage that maximizes shareholders' wealth. That is, the leverage choice itself is an 
agency problem: managers may deviate from value maximising capital structure choices and thus make themselves comfortable to pursue their own self-interest.

Several empirical studies provide evidence that corporate governance mechanisms are associated with the use of debt capital in the capital structure. For example, Friend and Lang (1988) show that the level of leverage is negatively related to management's shareholding, implying that managers who have large stakes in the corporation use less corporate debt in order to reduce their non-diversifiable firm specific risk associated with their human capital vested in the firm. That is the use of higher debt ratios results in greater agency costs to management than to public investors $^{2}$. In contrast, Mehran (1992), reports a positive relationship between equity owned by managers and firms' leverage, meaning that equity ownership provides managers with the incentive to use more debt capital so as to maximise their own wealth and outside shareholders' wealth. In addition, many empirical studies (e.g., Merhan, 1992; Berger, Ofek, \& Yermack, 1997; Brailsford, Oliver, \& Pua, 2002) show that other governance mechanisms such as the monitoring by outside block-holders and independent directors are positively associated with the increased use of debt-equity ratios in firms. A positive relation between external block holders and leverage suggests that large shareholders have greater incentives to monitor the management, resulting in decreased managerial opportunistic behaviour and thus lower agency costs.

Taken together, theoretical and empirical studies using agency theory as a theoretical framework suggest that conflicts of interest between managers and shareholders, managerial incentives, controlling shareholders' motives and the existing corporate governance structure in the firm have significant influence on the capital structure choices made by managers (Jensen \& Meckling, 1976; Berger et al., 1997; Faccio, Lang, \& Young, 2010). Therefore, a firm's observed capital structure is the result of the combination of managers' incentive, controlling shareholders' objectives and the robustness of the governance mechanisms in place to ensure the interest of outside shareholders or minority shareholders as well as the traditional financial determinants that have been typically used to explain capital structure choices.

Yet, only a very limited number of empirical works have focused on the impact of corporate governance on

\footnotetext{
2 This is consistent with an argument by Amihud and Lev (1981). According to which managers are unable to minimise their risk of investment since their investment ties up with un-diversifiable human capital vested in the firm whereas public investors can diversify their investment through investing in a well-diversified portfolio.
}

corporate financing decisions of Chinese listed firms (e,g., Wen, Rwegasira, \& Bilderbeek, 2002; Huang \& Song, 20006; Zou \& Xiao 2006). A common feature of all these studies based on Chinese listed companies is that they use data before 2005 and they have failed to consider potential endogeniety and the dynamic nature of firm's capital structure decisions ${ }^{3}$. Therefore, these studies do not consider changes occurred after the major split-share reform initiated by Chinese Securities Regulatory Committee (CSRC hereafter) and Chinese government in 2005. The aim of the 2005 split-share structure reform is to convert non-tradable shares into tradable shares in order to facilitate the liquidity in the secondary market. Before implementing the reform, the non-tradable shareholders of a firm have to negotiate with tradable shareholders to ensure that they get a suitable compensation package before trading occurs ${ }^{4}$. Although some recent empirical work (e.g., Boateng, Cai, Borgia, Gang Bi, \& Ngwu, 2017) consider data after 2005, they do not consider the possible effects of agency conflicts between managers and shareholders or effect of governance mechanisms on the capital structure in a unified framework. There have been significant changes in the ownership structure after 2005 split share reform especially the private and managerial ownership have significantly increased. Moreover, empirical studies from developed countries (for example, Berger et al., 1997) employ a wide range of corporate governance variables to study the linkages between corporate governance and capital structure decisions.

Therefore, it is clear that existing studies on the link between capital structure decisions and corporate governance in the context of Chinese financial market are incomplete. Given the tremendous changes in the corporate governance system, it becomes therefore imperative to investigate the impact of recent changes in ownership structure and the corporate governance system on Chinese firms' financing decisions. This is the objective of our study.

In this study, we find a strong positive relationship between managerial shareholding and total leverage. We also find that managerial ownership only affects the leverage decisions of private firms in the post-2005 split share reform period. While state ownership and foreign ownership negatively influence leverage decisions, legal person shareholding positively influences leverage decisions for state controlled firms. Finally, we also find that

\footnotetext{
3 One exception is Qian et al. (2009) who use of 650 Chinese publicly listed companies over the period 1999 to 2004 to examine the dynamic nature of capital structure model of Chinese listed companies.

4 The compensation package/ plan should be approved by $2 / 3$ of the total voting shareholders and the voting tradable shareholders.
} 
the board structure variables (board size and board composition/proportion of independent directors) do not influence firms' capital structure decisions.

This study contributes to the literature on the linkage between corporate governance and capital structure decisions in the context of emerging markets and particularly in China, the largest emerging economy in the world. Furthermore, the existing studies have examined subset of governance mechanisms, usually using only one or two governance variables. In this study, for the first time we include all the ownership structure, and board structure variables as well as other control variables in a unified framework in an attempt to develop a better capital structure model that could explain leverage ratio in the context of Chinese listed firms.

The reminder of the paper proceeds as follows. Section 2 describes the theoretical background on corporate governance and capital structure decisions and develops testable hypotheses. Section 3 presents baseline models and discusses our estimation methodology. Section 4 describes data and presents some descriptive statistics. In Section 5, we discuss our empirical results, before drawing some conclusions in Section 6.

\section{Literature Review and Hypotheses}

Traditionally two major theories, namely, the static tradeoff and pecking order theories are used to explain the use of debt capital in the capital structure. However, these theories are based on the assumption that the interest of the managers of a corporation with dispersed ownership is always aligned with that of shareholders. That is, managers take only value maximising financing decisions. In contrast, the agency theory assumes that self-interested managers always pursue their own objectives at the expenses of shareholders (Jensen \& Meckling, 1976). The agency cost of outside equity (i.e. equity shares held by anyone outside of the firm) arises from the conflicts between shareholders and managers because managers do not hold total residual claims in a large corporation with diffuse ownership, thus cannot gain entirely from their value maximizing activities. Therefore, managers may exert less effort in managing the firm's resources and may have tendency to transfer the firm's resources for their own personal benefits. The managers bear the entire costs of refraining from these activities, but capture only a fraction of the gain. As a result, they do not pursue their activities in a manner that maximizes shareholders wealth, meaning that they consume more perquisites, invest in unrelated businesses to build empires (such as corporate jets, luxurious offices etc.) and make suboptimal financing decisions (e.g., mangers may use less debt capital to avoid risk). Furthermore, Faccio et al. (2010) who investigate controlling shareholders' expropriation of outside shareholders' interests in East Asian and European economies argue that the governance role of leverage depends on the structure of firm ownership and control. We next develop the hypotheses relating each governance mechanism with the use of leverage in the capital structure.

\subsection{Ownership Structure}

Ownership structure of Chinese listed companies is very unique and arguably the government dominates in their governance structure (Chen \& Strange, 2005; Bhabra, Liu, \& Tirtiroglu, 2008). There are three main types of ownership in Chinese PLCs, namely, state ownership, legal-person ownership (i.e. institutional investors), and domestic individual ownership (tradable A-shares). In addition foreign and managerial ownership also play important role in the decisions of firms (Bhabra et al., 2008). Since these different ownership groups have different objectives, capabilities and incentives, they are likely to have an important influence in the capital structure choices of firms in China. Before the 2005 split-share structure reform in April 2005, non-tradable shares (which include both state and legal-person shareholding) represented about two-third of total outstanding shares (Bhabra et al., 2008). Only onethird of total outstanding shares were tradable in the stock exchanges for outside individual investors. However, after the 2005 split-share reform, the picture has changed for the reverse, state, legal person and A-shareholders held about $9 \%, 10 \%$ and $66 \%$ respectively by the end of 2010 . In case of managerial ownership (i.e. shares owned by CEOs, directors, supervisors and top management), the share was less than $1 \%$ before 2005 but it has increased to about $8 \%$ by the end of 2010. This shows that Chinese listed firms' ownership structure is becoming more similar to what is observed in Western countries.

\subsubsection{Managerial Ownership}

As we discussed earlier, managerial direct incentives are an important determinant of corporate financial decisions (Jensen \& Meckling, 1976) ${ }^{5}$. Previous empirical studies based on US firms (Mehran, 1992; Berger et al., 1997) document a positive relationship between managerial ownership and leverage, implying that managers whose financial incentives are more closely aligned with outside shareholders' wealth will pursue more leverage in order to inflate the value of the firm. From another perspective (i.e.

\footnotetext{
${ }^{5}$ The position of the CEO is equivalent to that of general manager in China.
} 
entrenchment motives), it is also shown that entrenched managers might increase leverage beyond the optimal point in order to raise their own voting power and reduce the possibility of takeover (Stulz, 1988; Harris \& Raviv, 1988).

A counter-argument is provided by Friend and Lang (1988), who show that managerial shareholding is negatively related to debt ratios, implying that managers prefer less leverage since their wealth is largely tied up in non-diversifiable human capital and personal investment vested in the firm. Al-Fayoumi and Abuzayed (2009) find a similar relationship between managerial ownership and leverage in Jordanian industrial firms. Furthermore, other studies such as Brailsford et al. (2002) and Florackis and Ozkan (2009) report a significant non-monotonic relationship (inverted $U$ shaped) between managerial ownership and leverage for the sample of Australian and UK firms, respectively, consistent with the alignment and entrenchment effects.

In the context of China, only a paper by Huang and Song (2006) examines the effects of managerial ownership (with a definition similar to ours) on capital structure decisions and find a negative relationship with leverage. They conclude that Chinese managers are generally risk averse, thus leading to pursue less leverage ${ }^{6}$. However, their results should be cautiously interpreted since they do not control for unobserved heterogeneity or endogeneity which may create a spurious correlation between managerial shareholdings and leverage. We expect to observe a significant positive relationship between managerial shareholding and the level of leverage, consistent with the incentive effect, as Chinese managers' shareholdings have increased considerably after the 2005 split-share reform. Therefore, we hypothesise that:

$\mathbf{H}_{1:}$ There is a significant positive relationship between managerial shareholding and the level of leverage

\subsubsection{Legal-person Ownership (Institutional Shareholding)}

Arguments based on agency theory predict that institutional shareholders (in Chinese terminology these are known as legal-person shareholders) can reduce agency costs by closely monitoring managerial opportunistic behaviour. This is because both the benefits of monitoring cash flow and the ability to access various sources of

\footnotetext{
${ }^{6}$ Most of the previous studies that examine capital structure decisions of Chinese listed firms, do not include managerial ownership as a main variable in their studies (Wen et al, 2002; Zou and Xiao, 2006; Qian et al., 2009), since managerial share ownership was significantly lower in the listed firms' ownership structure. However, we include managerial ownership as it is about $8 \%$ by the end of 2010 .
}

information and resources provide institutional investors necessary incentives and capabilities to bear the costs of monitoring management of the firms where they have large ownership stake (Coffee, 1991; Sun, Ding, Guo, \& Li, 2016). Therefore, leverage should increase in the presence of institutional shareholders. A counter argument suggests that institutional shareholders may substitute for the disciplinary role of leverage in the capital structure and thus, predicts a negative relationship between institutional shareholders and leverage (Grier \& Zychowicz, 1994). In Chinese context, some studies find no significant role for legal person shareholders in capital structure decisions (Huang \& Song, 2006; Zou \& Xiao, 2006). Yet, Bhabra et al. (2008) find that legal person shareholding in entrepreneurial private firms has a positive impact on leverage. We test the following hypothesis:

$\mathbf{H}_{2}$ : There is a positive significant relationship between legal-person ownership and leverage.

\subsubsection{State Ownership}

When the state is a shareholder in a firm, the firm may obtain necessary resources without much problem. In general, research suggests that due to the following reasons, state owned firms are more likely to have a higher leverage ratio than other firms. Firstly, as the government provides a guaranty for loans and most of the banks in China are stateowned, the direct and indirect presence of the state in firms reduces the financial distress costs of the firms (Bhabra et al., 2008). Secondly, leverage can be used by state agents (as a controlling shareholder) to fund resources in order to pursue their own economic and/or social objectives at the expense of minority shareholders without diluting state control over the corporations (Stulz, 1988; Xu \& Wang, 1999; Faccio et al., 2010). Finally, as state controlled firms face severe agency problems due to the lack of direct residual claims (Berkman, Cole, \& Fu, 2002), they should benefit more than other firms from the disciplining role of debt capital (Jensen \& Meckling, 1976; Jensen 1986).

However, the Chinese evidence remains controversial. For example, Qian, Tian, and Wirjanto (2009) find a positive relationship between state shareholding and leverage. By contrast, others, e.g. Zou and Xiao (2006) and Bhabra et al. (2008), find that state ownership has no impact on leverage. Bhabra et al. (2008) interpret this result as evidence for that the State's protectionist role does not affect the financial distress costs of their sample firms. Lin and Bo (2011) suggest that state banks have become semi-commercial banks and they have started to act indiscriminately towards all the firms and thus, state ownership in firms no longer facilitates easy access of finance from state owned banks. Therefore, the risk averse managers in the state owned 
firms with weak managerial incentives (Kato \& Long, 2006, 2011) are more likely to prefer a low level of leverage. Furthermore, Chang, Chen, and Liao (2014) note that SOEs not only may face fewer restrictions in equity issuance but also might receive favorable treatments when applying for seasoned equity financing. In line with these reasoning, we would expect that state ownership should be negatively associated with leverage. Therefore, we hypothesize that:

$\mathbf{H}_{3}$ : There is a significant negative relationship between state ownership and leverage.

\subsubsection{Foreign Investors}

In Chinese listed firms, foreign investors are either founder shareholders (e.g., Hong Kong incorporated industrial firms) or shareholders of B-shares (e.g., foreign banks or mutual funds). In the case of Chinese listed firms, foreign investors (who are often large institutional investors with diversified portfolios) normally have low ownership stakes in them and thus they may find debt as a preferable monitoring mechanism to constrain managerial selfinterested behaviour of managers in their portfolio firms (Zou \& Xiao, 2006). Furthermore, foreign investors in nascent markets like China may face severe asymmetric information problems compared to domestic investors (Wiwattanakantang, 1999), implying that they are likely to rely on debt as a mechanism for monitoring managers' opportunistic behaviour. In the context of China, while Zou and Xiao (2006) find that foreign ownership does not have any significant impact on leverage, Bhabra et al. (2008) find that there is a positive relationship between foreign ownership and leverage. In line with these reasoning, we expect that:

$\mathbf{H}_{4}$ : There is a significant positive relationship between foreign shareholding and leverage.

\subsection{Board Structure}

\subsubsection{Board Size}

A well-functioning board of directors is an important internal governance mechanism which may affect agency costs and firms' decisions such as capital structure decisions. In their theoretical articles, Jensen (1986) suggests that a larger board should be associated with higher leverage since debt is an effective mechanism to constraint agency costs of free cash flow. By contrast, Lipton and Lorsch (1992) and Jensen (1993) argue that boards become less effective as they increase in size and more susceptible to the influence of CEOs. Therefore, the decision-making problems become more sever with large boards. Debt financing, which constrains managers' ability to use free cash flow for the consumption of perquisites and empire building, may not be easily accepted. Therefore, larger boards are more likely to be negatively related to leverage.

Berger et al. (2007) and Florackis and Ozkan (2009) find that board size is inversely related to leverage, meaning that large boards are associated with coordination, communication and decision-making problems and thus, ineffective in preventing entrenched CEOs from pursuing lower leverage. In addition, Wiwattanakantang (1999) and Abor (2007) also provide evidence suggesting that larger boards are ineffective in encouraging CEO to pursue high level of leverage for firms in emerging markets. By contrast, Ghosh, Giambona, Harding, and Sirmans (2011) report a significant positive relationship between large boards and leverage. Wen et al. (2002) find an insignificant relationship between board size and leverage. Consistent with most of the empirical findings, if small boards are indeed more effective at monitoring and directing managers to high level of leverage, then we would expect a negative relationship between board size and leverage. Our hypothesis is that:

$\mathbf{H}_{5}$ : There is a significant negative relationship between board size and leverage.

\subsubsection{Board Composition (The Proportion of Independent Directors)}

The agency theory suggests that since independent directors who are generally concerned about their reputations and social status, have incentives to monitor management, the top managers generally face more careful monitoring (Fama \& Jenson, 1983; Weisbach, 1998). Therefore, Jensen (1986) argues that firms whose boards are dominated by outside directors have higher levels of leverage which is an effective mechanism for restricting managerial control of free cash flow. The resource dependence perspective developed by Pfeffer and Salancick (1978) highlights, on the other hand, that external directors boost a firm's ability to protect itself against the external environment, reduce uncertainty, or co-opt resources that increase the firm's ability to raise funds or increase its status and recognition. A high proportion of outside directors are therefore believed to be associated with higher levels of leverage.

Consistent with the above arguments, Berger et al. (1997) find a positive association between the proportion of outside directors and leverage. In contrast, Wen et al. (2002) find a significant negative relationship between number of outside directors on the board and leverage using the Chinese listed firms' data over the period 1996-1998. They suggest that outside directors monitor the management more actively 
and hence outside directors may act as substitute for the disciplinary role of debt in the capital structure. However, after decades of improvement in the corporate governance of Chinese listed companies, if independent members are more effective at monitoring and directing management's choices, we would expect a positive relationship between the proportion of independent directors and level of leverage. Hence, we hypothesise that:

$\mathbf{H}_{6}$ : There is a significant positive relationship between the percentage of outside directors on the board and leverage.

\section{Model Specification and Estimation Methodology}

\subsection{Model Specification}

In order to test our hypotheses we first estimate the following equation

$$
\begin{aligned}
\text { lev }_{\text {it }}= & \beta_{0}+\beta_{1} \text { lev }_{\text {it- } 1}+\beta_{2} \text { Ipos }_{i t}\left(\text { sos }_{i t}\right)+\beta_{3} \text { dstmshare }_{i t} \\
& +\beta_{4} \text { fcap }_{i t}+\beta_{5} \text { bodsize }_{i t}+\beta_{6} \text { indes }_{i t}+\beta_{7} \text { size }_{i t} \\
& +\beta_{8} \text { profit }_{i t}+\beta_{9} \text { tang }_{i t}+\beta_{10 \text { growth }_{i t}}+\beta_{11} \text { nontaxshd }_{i t} \\
& +\beta_{12} \text { vol }_{i t}+\beta_{13} \text { firmage }_{i t}+v_{i}+v_{t}+v_{j}+v_{k}+e_{i t .}
\end{aligned}
$$

where $i$ indexes firm, $t$ years. The term $v_{i}, v_{t}, v_{j}$, and $v_{k}$ represent time-invariant firm specific fixed effects, timespecific effects, industry effects, and effects of regional differences, respectively; $e_{i t}$ is a random/ idiosyncratic error term. Lemmon, Roberts, and Zender (2008) provide strong evidence that firm-specific effect $\left(v_{i}\right)$ unobservable characteristics of the firm such as the quality of management, managers' attitudes towards risk, and market reputation have a significant impact on firms' capital structure decisions. Furthermore, time-specific effects $\left(v_{t}\right)$, which we control for by including time dummies, captures macroeconomic factors such as interest rates, inflation and business cycle effects

On the left hand side of the Equation (1), our dependent variable is the leverage ratio of firm $i$ in year $t$. On the right

\begin{tabular}{|c|c|c|c|c|}
\hline Variables & Name & & Measures & Expected sign \\
\hline \multicolumn{5}{|l|}{ Dependent Variable } \\
\hline Leverage & lev & & Total debt / total assets & \\
\hline \multicolumn{5}{|l|}{\begin{tabular}{|l|} 
Governance variables \\
\end{tabular}} \\
\hline Managerial ownership & dstmshare & & $\begin{array}{l}\text { Shares owned directly by directors, supervisors \& top management / total number of } \\
\text { outstanding shares }\end{array}$ & $+(\mathrm{H} 1)$ \\
\hline Legal person shares & Ipos & & Shares owned by legal persons/ total number of outstanding shares & $+(\mathrm{H} 2)$ \\
\hline State shares & sos & & State owned shares/ total number of outstanding shares & $-(\mathrm{H} 3)$ \\
\hline Foreign investors & focap & & Foreign investor owned shares/ total number of shares & $+(\mathrm{H} 4)$ \\
\hline Board size & Inbodsize & & Natural logarithm of total number of directors on the board & $-(\mathrm{H} 5)$ \\
\hline \begin{tabular}{|l|}
$\begin{array}{l}\text { Board composition } \\
\text { (independent directors) }\end{array}$ \\
\end{tabular} & indes & & Percentage of independent directors on the board & $+(\mathrm{H} 6)$ \\
\hline \multicolumn{5}{|l|}{ Control variables } \\
\hline Size & size & & Natural logarithm of total real assets & + \\
\hline Profitability & profit & & $\begin{array}{l}\text { ROA =Return on assets = Earnings before interest, taxes and depreciation / total } \\
\text { assets }\end{array}$ & - \\
\hline Tangibility & tang & & Net fixed assets/ Total assets & + \\
\hline Growth opportunities & growth & & $\begin{array}{l}\text { Ratio of the sum of the market value of equity and the book value of debt to the book } \\
\text { value of total assets } \\
\text { Non-tradable share price is used to calculate as the market value of the tradable } \\
\text { equity. }\end{array}$ & - \\
\hline Non-debt tax shield & notaxshd & & Depreciation / total assets & - \\
\hline Volatility & vol & & $\begin{array}{l}\text { Standard deviation of the first differences of earnings before taxes and depreciation } \\
\text { over the four years preceding the sample period, divided by average total assets for } \\
\text { that period. }\end{array}$ & - \\
\hline Firm age & firmage & & Natural logarithm of the number of years since the establishment of the firm & + \\
\hline Year dummies & $v_{t}$ & & Year dummies for the years 2003 to 2010 & \\
\hline Industry dummies & $v_{j}$ & & $\begin{array}{l}\text { CSMAR B classification: } 5 \text { industries : Utilities, Properties, Conglomerates, Industry, } \\
\text { Commerce (except financial industries) }\end{array}$ & \\
\hline Regional dummies & $v_{k}$ & & $\begin{array}{l}\text { Dummies indicating whether the firm is located in the Coastal, Western, or Central } \\
\text { region of China }\end{array}$ & \\
\hline
\end{tabular}
hand side a set of ownership and corporate governance variables are included as explanatory variables. In addition,

Table 1: Definition of Variables

Notes: We exclude CEO duality from the analysis since its variation is not sufficient for it to be included in our model as an independent variable. It is typically $15 \%$ over the period of 2003 to 2010 . ' + ' means that leverage increases with the variables, '-' means that leverage decreases with the variables. 
the study uses seven important firm characteristics namely, size, profitability, tangibility, growth opportunities, non-debt tax shield, volatility, firm age as control variables The expected relationship between control variables and leverage are primarily guided by relevant theories as well as previous empirical studies.

Prior studies (e.g. Lemmon et al., 2008) emphasize that capital structure is more likely to be highly persistent due to the adjustment costs and other market imperfections. Therefore, in Equation (1) we include the lagged dependent variable amongst the explanatory variables to capture the dynamic effects in the capital structure decisions (Florakis \& Ozkan, 2009). The list of variables used in the paper, their definition and expected sign are summarized in Table 1.

\subsection{Estimation Methodology}

We use the system GMM methodology with two step robust standard errors which can control for the correlation of errors over time, heteroskedasticity across firms, simultaneity, and measurement errors due to the utilization of orthogonal conditions on the variance-covariance matrix (Arellano \& Bover, 1995; Blundell \& Bond, 1998). To evaluate whether our instruments are legitimate and our model is correctly specified, we first use the test for first and second-order (i.e. AR (1) and AR (2)) serial correlation of the residuals in the differenced equation. We next use the Sargan test (also known as $\mathrm{J}$ test) which tests the overidentifying restrictions, concerning the validity of instruments.

\section{Data and Preliminary Analysis}

In this section, we describe the dataset and sample that is used in our study. This section also provides a discussion on summary statistics and correlation analysis of our variables.

\subsection{Data and Sample Selection}

Our sample includes all the publicly held firms that have been listed on the Shanghai and Shenzhen stock exchanges over the period of 2003 to 2010. Data are collected from the China Stock Market and Accounting Research (CSMAR) database and Sino-fin. We first delete firms in the financial industry, since their capital structure is subject to many regulations. We then remove the potential outliers (i.e., extreme observations) by deleting observations below the $1^{\text {st }}$ and above the $99^{\text {th }}$ percentile of all our regression variables, expect dummy variables. Our final sample has 1844 Chinese firms and covers an unbalanced panel of 9624 firm-year observations. When using the system GMM estimator, since we lag all the right hand side variables twice or more to obtain suitable instruments, the final sample comes down to 6414 firm year observations.

\subsection{Summary Statistics and Correlation Analysis}

Table 2 presents descriptive statistics and correlation matrix for the variables used in our regression analysis. The average leverage (lev) ratio for the sample firms is about $50 \%$. As for the ownership structure, average managerial share ownership (dstmshare) for the sample firms is $2.5 \%$ of the total outstanding shares. Our sample firms on average have $25.3 \%$ and $16.1 \%$ of shares owned by state (sos) and legal person (Ipos), respectively. The mean of the board size is 9.4 with the proportion of independent directors (indes) of $35 \%$.

With regard to firm characteristics, the mean of firm size (size) is 1.463 billion $\mathrm{RMB}^{7}$ Chinese firms have an average profitability (profit) of $7.4 \%$, an average tangibility (tang) of $46 \%$, and average growth opportunity (growth) of $20.82 \%$. Average non- debt tax shield (notaxshd) for the sample firms is $2.5 \%$ while average volatility $(\mathrm{vol})$ for the sample firms is $3.7 \%$. The average level of firm age (firmage) is 10.5 years.

Turning to the correlation matrices, legal person shares exhibit a positive significant correlation with total leverage, as we hypothesised $(\mathrm{H} 2)$. State shares exhibit a negative but insignificant correlation with leverage. Managerial ownership shows a negative and statistically significant correlation with the leverage ratio. This unexpected sign of managerial ownership may be due to the confounding factors behind such association. Our multivariate regressions analysis using econometric techniques should account for this issue.

Table 2 shows a high negative correlation between state and legal person shareholders (-0.51), implying that multicollinearity is likely to be a problem ${ }^{8}$. Therefore, in order to mitigate the problem, we include one and drop the

\footnotetext{
${ }^{7}$ It should be noted that although firm size is measured as the logarithm of total real assets in the regression analysis, the figure reported in the descriptive statistics in Table 1 is not in logarithms as actual value is easier to interpret.

${ }^{8}$ When we calculate the correlation on a yearly basis, we find that correlation coefficient between Ipos and sos is above -0.8 during the period before 2005. This is similar to the one reported by Yuan et al. (2008) who find a correlation coefficient of -0.88 between lops and sos. We also calculate the variance inflation factor (VIF), and note that the VIF is 9.2 (which is closer to the threshold of 10), which suggests that the observed high correlation coefficient between state shareholdings and legal person shareholdings may cause problems in our regressions.
} 
Table 2: Summary Statistics and Pearson Correlation Matrices

\begin{tabular}{|c|c|c|c|c|c|c|c|c|c|c|c|c|c|c|c|c|c|}
\hline & & Mean & $\begin{array}{l}\text { Std. } \\
\text { Dev. }\end{array}$ & 1 & 2 & 3 & 4 & 5 & 6 & 7 & 8 & 9 & 10 & 11 & 12 & 13 & 14 \\
\hline 1 & lev & 0.503 & 0.214 & 1.00 & & & & & & & & & & & & & \\
\hline 2 & dstmshare & 0.025 & 0.089 & $-0.17^{*}$ & 1.00 & & & & & & & & & & & & \\
\hline 3 & Ipos & 0.161 & 0.207 & $0.03^{*}$ & 0.00 & 1.00 & & & & & & & & & & & \\
\hline 4 & sos & 0.253 & 0.244 & -0.02 & $-0.26^{*}$ & $-0.51^{*}$ & 1.00 & & & & & & & & & & \\
\hline 5 & fcap & 0.036 & 0.101 & -0.01 & $-0.05^{*}$ & $-0.05^{*}$ & $-0.03^{*}$ & 1.00 & & & & & & & & & \\
\hline 6 & Inbodsize & 9.390 & 1.856 & $0.04^{*}$ & $-0.07^{*}$ & $-0.07^{*}$ & $0.14^{*}$ & $0.06^{*}$ & 1.00 & & & & & & & & \\
\hline 7 & indes & 0.351 & 0.042 & -0.00 & $0.08^{*}$ & \begin{tabular}{|l|}
-0.02 \\
\end{tabular} & $-0.10^{*}$ & 0.01 & $-0.27^{*}$ & 1.00 & & & & & & & \\
\hline 8 & size & 1.463 & 2.471 & $0.20^{*}$ & $-0.15^{*}$ & $-0.21^{*}$ & $0.14^{*}$ & $0.17^{*}$ & $0.21^{*}$ & $0.03^{*}$ & 1.00 & & & & & & \\
\hline 9 & profit & 0.074 & 0.063 & $-0.33^{*}$ & $0.08^{*}$ & $-0.06^{*}$ & 0.02 & $0.03^{*}$ & $0.06^{*}$ & -0.00 & $0.19^{*}$ & 1.00 & & & & & \\
\hline 10 & tang & 0.460 & 0.165 & $0.20^{*}$ & $-0.15^{*}$ & $-0.10^{*}$ & $0.11^{*}$ & $0.03^{*}$ & $0.09^{*}$ & $-0.03^{*}$ & $0.16^{*}$ & $0.09^{*}$ & 1.00 & & & & \\
\hline 11 & growth & 2.082 & 1.237 & $-0.22^{*}$ & $0.22^{*}$ & 0.01 & $-0.19^{*}$ & $-0.04^{*}$ & $-0.09^{*}$ & $0.06^{*}$ & $-0.30^{*}$ & $0.21^{*}$ & $-0.21^{*}$ & 1.00 & & & \\
\hline 12 & nontaxshd & 0.025 & 0.015 & $0.2{ }^{*}$ & $-0.16^{*}$ & $0.05^{*}$ & $-0.06^{*}$ & $0.05^{*}$ & $-0.09^{*}$ & $0.03^{*}$ & $-0.12^{*}$ & $-0.21^{*}$ & -0.01 & $0.07^{*}$ & 1.00 & & \\
\hline 13 & vol & 0.037 & 0.049 & -0.02 & $-0.12^{*}$ & $-0.12^{*}$ & $0.12^{*}$ & $0.10^{*}$ & $0.08^{*}$ & $-0.04^{*}$ & $0.06^{*}$ & $0.23^{*}$ & $0.50^{*}$ & $-0.08^{*}$ & $0.06^{*}$ & 1.00 & \\
\hline 14 & firmage & 10.543 & 4.132 & $0.25^{*}$ & $-0.27^{*}$ & $-0.08^{*}$ & $-0.22^{*}$ & $0.06^{*}$ & $-0.05^{*}$ & $0.03^{*}$ & $0.15^{*}$ & $-0.10^{*}$ & $0.08^{*}$ & $-0.03^{*}$ & $0.29^{*}$ & $0.02^{*}$ & 1.00 \\
\hline
\end{tabular}

Notes: * denotes significance at the $5 \%$ level. See Table 1 for definitions of all variables.

other at one time. Previous studies that involve the ownership structure of Chinese listed corporations also do so (for example, Zou and Xiao, 2006 and Yuan et al., 2008). Moreover, except for these variables, the correlation coefficients between other explanatory variables are generally moderate.

As for the control variables, while firm size and tangibility exhibit a positive association with total leverage, profitability and growth opportunities show a negative correlation with total leverage. These results are consistent with the theories and our expectations.

\section{Empirical Results}

This section discusses the empirical results. As we discussed in methodology section, we mainly rely on the estimation results of the dynamic system GMM estimator for inferences, which enable us to control for potential unobserved heterogeneity, endogeneity and persistency in capital structure decisions. In addition, we report estimates from static models obtained using the pooled OLS and firm fixed effects regressions which enable us to directly compare our results with previous studies based on developed countries as well as in the context of Chinese firms. Additionally, we carry out many robustness tests using alternative model specifications and sub-sample of firms.

\subsection{The Effects of Ownership Structure and Board Structure on Capital Structure Decisions}

The system GMM estimation results of our baseline model Eq. (1) are reported in columns 1-2 of Table 3. As sos and Ipos are highly correlated, regressions estimates are reported separately for regressions containing one or the other.

As can be seen in columns 1-2 of Table 3, the estimated impact of managerial ownership (dstmshare) on total leverage becomes positive and statistically significant, in line with our hypothesis $(\mathrm{H} 1)^{9}$. Furthermore, its magnitude is also economically more significant: calculating the economic significance from column 5 , we find that incrementing managerial ownership by one-standard deviation increases leverage by $3.1 \%$ of its mean. This finding is consistent with the incentive alignment hypothesis of Jensen and Meckling (1976), suggesting that greater managerial shareholding provide managers with incentive to adopt more risky financial choices by using relatively more leverage. Moreover, the positive relationship may also imply that when managerial shareholding increases they choose higher leverage ratios as a signal for committing to low agency costs to outsiders. This finding is consistent with previous findings by Mehran (1992), Berger et al. (1997) for US firms.

The estimated coefficient on legal person shareholding (Ipos) is significantly positive, consistent with our expectation $\left(\mathrm{H}_{2}\right)$, in the OLS regressions (column 1). Yet, as can be seen in column 5 of Table 3 , after controlling for potential unobserved heterogeneity and endogeneity, legal person shareholding is found not to have significant impact on leverage though it bears a positive sign. This is consistent with the previous empirical findings (e.g. Zou \& Xiao, 2006; Chen \& Strange, 2005).

\footnotetext{
${ }^{9}$ We also tested whether managerial ownership is non-linearly related to leverage, but we do not find such relationship in our data.
} 
Table 3: The Effects of Ownership Structure and Board Structure on Capital Structure Decisions

\begin{tabular}{|c|c|c|c|c|c|c|}
\hline & \multicolumn{2}{|c|}{ Full sample } & \multirow{2}{*}{$\begin{array}{c}\text { Private } \\
(3)\end{array}$} & \multicolumn{2}{|c|}{ State } & \multirow{2}{*}{$\begin{array}{c}\text { Reform } \\
(6)\end{array}$} \\
\hline & (1) & (2) & & (4) & (5) & \\
\hline \multicolumn{7}{|l|}{ Governance variables } \\
\hline \multirow[t]{2}{*}{ dstmshare } & 0.173 & 0.116 & 0.189 & 0.073 & 0.132 & \\
\hline & $(0.051)$ & $(0.053)$ & $(0.086)$ & $(0.626)$ & $(0.661)$ & \\
\hline \multirow[t]{2}{*}{ dstmshare ${ }^{*}$ post_reform } & & & & & & 0.114 \\
\hline & & & & & & $(0.058)$ \\
\hline \multirow[t]{2}{*}{ dstmshare*pre_reform } & & & & & & 0.100 \\
\hline & & & & & & $(0.097)$ \\
\hline \multirow[t]{2}{*}{ Ipos } & 0.010 & & -0.042 & 0.070 & & 0.027 \\
\hline & $(0.026)$ & & $(0.031)$ & $(0.032)$ & & $(0.020)$ \\
\hline \multirow[t]{2}{*}{ sos } & & $-0.043^{* *}$ & & & $-0.063^{* \pi}$ & \\
\hline & & $(0.018)$ & & & $(0.027)$ & \\
\hline \multirow[t]{2}{*}{ fcap } & -0.205 & -0.225 & -0.150 & -0.054 & -0.101 & -0.201 \\
\hline & $(0.102)$ & (0.099) & $(0.119)$ & $(0.164)$ & $(0.172)$ & $(0.105)$ \\
\hline \multirow[t]{2}{*}{ Inbodsize } & 0.029 & 0.044 & 0.072 & 0.067 & 0.084 & 0.056 \\
\hline & $(0.044)$ & $(0.043)$ & $(0.085)$ & $(0.049)$ & $(0.051)$ & $(0.044)$ \\
\hline \multirow[t]{2}{*}{ indes } & 0.068 & 0.163 & 0.260 & 0.192 & 0.152 & 0.189 \\
\hline & $(0.184)$ & $(0.168)$ & $(0.393)$ & $(0.157)$ & $(0.201)$ & $(0.164)$ \\
\hline \multicolumn{7}{|l|}{ Control variables } \\
\hline \multirow[t]{2}{*}{$l e v_{i t-1}$} & 0.856 & 0.862 & 0.926 & 0.819 & $0.823^{\mathrm{knm}}$ & 0.857 \\
\hline & $(0.041)$ & $(0.035)$ & $(0.056)$ & $(0.050)$ & $(0.049)$ & $(0.036)$ \\
\hline \multirow[t]{2}{*}{ size } & $0.018^{* 11}$ & $0.023^{n+1}$ & $0.033^{\prime \prime \prime}$ & 0.020 & 0.020 & 0.022 \\
\hline & $(0.008)$ & $(0.007)$ & $(0.016)$ & $(0.009)$ & $(0.009)$ & $(0.007)$ \\
\hline \multirow[t]{2}{*}{ profit } & -0.593 & -0.579 & -0.638 & -0.557 & -0.487 & -0.576 \\
\hline & $(0.108)$ & $(0.108)$ & $(0.159)$ & $(0.135)$ & $(0.144)$ & $(0.105)$ \\
\hline \multirow[t]{2}{*}{ tang } & -0.020 & -0.076 & -0.194 & -0.063 & -0.027 & -0.073 \\
\hline & $(0.079)$ & $(0.050)$ & $(0.126)$ & $(0.067)$ & $(0.077)$ & $(0.051)$ \\
\hline \multirow[t]{2}{*}{ growth } & -0.026 & -0.027 & -0.025 & -0.022 & -0.024 & -0.021 \\
\hline & $(0.012)$ & $(0.013)$ & $(0.013)$ & $(0.011)$ & $(0.013)$ & $(0.010)$ \\
\hline \multirow[t]{2}{*}{ nontaxshd } & 0.604 & 0.600 & 3.787 & 0.420 & -0.033 & 0.589 \\
\hline & $(0.724)$ & $(0.478)$ & $(1.649)$ & $(0.851)$ & $(0.975)$ & $(0.481)$ \\
\hline \multirow[t]{2}{*}{ vol } & -0.362 & $-0.171^{2}$ & -0.310 & $-0.433^{\prime 2}$ & $-0.421^{\prime \prime}$ & $-0.168^{\prime \prime}$ \\
\hline & $(0.116)$ & $(0.079)$ & $(0.175)$ & $(0.154)$ & $(0.164)$ & $(0.078)$ \\
\hline \multirow[t]{2}{*}{ firmage } & 0.021 & 0.011 & 0.017 & 0.006 & 0.005 & 0.015 \\
\hline & $(0.008)$ & $(0.008)$ & $(0.016)$ & $(0.012)$ & $(0.014)$ & $(0.008)$ \\
\hline Constant & -0.463 & $-0.681^{-1 *}$ & $1.071^{\circ}$ & 0.699 & 0.711 & 0.718 \\
\hline & $(0.335)$ & $(0.301)$ & $(0.561)$ & $(0.366)$ & $(0.401)$ & $(0.284)$ \\
\hline Industry dummies & yes & yes & yes & yes & yes & yes \\
\hline Regional dummies & yes & yes & yes & yes & yes & yes \\
\hline Year dummies & yes & yes & yes & yes & yes & yes \\
\hline Firm fixed effects & yes & yes & yes & yes & yes & yes \\
\hline Observations & 6414 & 6414 & 2132 & 4256 & 4256 & 6414 \\
\hline F test & 107.067 & 97.600 & 55.176 & 66.556 & 68.591 & 93.993 \\
\hline$P$ value & 0.000 & 0.000 & 0.000 & 0.000 & 0.000 & 0.000 \\
\hline Sargan test ( $p$ values) & 0.339 & 0.800 & 0.405 & 0.566 & 0.531 & 0.462 \\
\hline$m 1$ (p-values) & 0.000 & 0.000 & 0.000 & 0.000 & 0.000 & 0.000 \\
\hline$m 2$ (p-values) & 0.819 & 0.685 & 0.590 & 0.752 & 0.676 & 0.759 \\
\hline
\end{tabular}

Notes: Cluster robust standard errors are reported in columns 1-4 (clustered on firms). Asymptotic standard errors robust to heteroskedasticity are reported in parentheses in column 5-6. For the system GMM regression, AR2 is a test for second-order serial correlation of the differenced residuals, asymptotically distributed as $N(0,1)$ under the null of no serial correlation. The Sargan test (also known as $\mathrm{J}$ test) of over-identifying restrictions is distributed as Chi-square under the null of instrument validity. We treat all right-hand side variables except firm age, volatility and dummy variables as potentially endogenous variables. ${ }^{* * *},{ }^{* *}$, and * denote significance levels of $1 \%, 5 \%$ and $10 \%$, respectively. See Table 1 for definitions of all variables.

Consistent with our hypothesis (H3), state ownership (sos) has a negative significant impact on leverage in columns 2 . A one standard deviation increase in state shareholding decreases leverage by approximately $2.08 \%$. This finding is inconsistent with Qian et al. (2009) but our results lend support to the argument that state banks have become semi-commercial banks and started to act indiscriminately towards all the firms, regardless of the state involvements in them (Lin \& Bo, 2011) and thus, managers in state controlled firms no longer enjoy easy access to finance from 
state owned banks. Therefore, the risk averse managers in the state owned firms with weak managerial incentives (Kato \& Long, 2006, 2011) are more likely to prefer a low level of leverage. Furthermore, this result may also imply that SOEs not only may face fewer restrictions in equity issuance but also might receive favorable treatments when applying for seasoned equity financing, thus use less debt (Lin \& Bo, 2011).

Different from what we hypothesised $\left(\mathrm{H}_{4}\right)$, foreign shareholding (fcap) is negatively related to leverage to OLS and the GMM regressions. Focusing on the column (1), a one standard deviation increase in foreign shareholding, decreases leverage by approximately $4.1 \%$. This result may be explained by the fact that as foreign ownership is relatively low in these firms, the foreign investors may therefore prefer to use less debt in their portfolio firms to avoid expropriation by controlling shareholders (Stulz, 1988; Xu \& Wang, 1999; Faccio et al., 2010).

Turning to the effects of board structure, our results suggest the absence of significant relationship between board structure variables [board size (Inbodsize) and independent directors (indes)] and leverage ratios of Chinese listed firms. Our empirical result for board size is consistent with previous findings of Wiwattanakantang (1999) and Wen et al. (2002). While our finding that independent directors do not affect capital structure decisions is consistent with criticism of Clarke $(2003,2006)$ among others that independent directors of Chinese PLCs have no necessary knowledge and experience on financial and strategic aspects of the firms they represent and they are added to the board just to meet the legal and regulatory requirements. This finding is consistent with empirical findings of Dixon, Guariglia, and Vijayakumaran (2017) in that they show that Chinese independent directors are not effective in influencing firms' decisions.

As for the control variables, most of the traditional determinants of leverage retain their sign and significance levels as expected. Furthermore, when we calculate the economic significance of these variables from column 6 , we find that incrementing size and firm age of one-standard deviation increase leverage by 0.11 times and 0.17 times (from column 5) of its mean, respectively whereas incrementing profitability, growth opportunities and volatility by one-standard deviation decreases leverage by $7.25 \%$, $6.61 \%$ and $2 \%$ of its mean, respectively.

The estimated coefficients on volatility $(\mathrm{vol})$ are significantly negative and consistent with previous studies (e.g, Zou \& Xiao, 2006) and with the trade-off and theory, suggesting that high volatility of earnings increases the probability of financial distress which in turn decreases firm's debt capacity. Firm age (firmage) attracts a positive and statistically significant coefficient with leverage ratios.

\subsection{Further Tests}

In this sub-section we verify whether our results are robust to using alternative model specifications and different sub-sample of firms.

\subsubsection{Estimating Separate Regressions for State and Non-state Firms}

In this section, we investigate how the impact of managerial ownership on the leverage differs between the sub-sample of state and non-state firms. This exercise is motivated considering that top executives who come from the state sector are generally appointed by party and government agencies (typically party secretaries, government officials or veteran socialist managers) (Walder, 2011). Therefore, Walder (2011) mentions managerial autonomy is limited in state controlled firms.

In contrast, top executives in the private sector may have begun their careers in the state sector. But, they have not been appointed by the state. The managers of the private sector have greater independency from the state agencies compared to their counterparts. Moreover, Walder (2011) notes that top executives who come from private sector get much higher levels of compensation and they are more likely to have a significant level of ownership stake. These developments indicate that managers of these companies play a major role, as they have to take ultimate decision of the company.

In the light of these considerations, in columns (3) - (5) of Table 3, we provide separate system GMM estimates of Equation (1) for state and non-state (private) firms. The results show that managerial ownership (dstmshare) only affects the leverage decisions of private firms, whilst the coefficient on managerial ownership is insignificant for state firms.

As can been seen in columns (3) and (4) of Table 3, legal person shareholding (Ipos) have a positive impact on leverage ratios of state firms, whilst the coefficient on legal person shareholding is insignificant for private firms ${ }^{10}$. Column 5 shows that state ownership (sos) negatively influences the leverage decisions of state firms. Moreover, the coefficient on foreign ownership (fcap) is insignificant for both firms. The absence of a significant relationship between board structure variables (board size and independent directors) and leverage ratios applies to both of the subsamples of state and non-state listed firms.

\footnotetext{
${ }^{10}$ When we use state ownership (sos) instead of legal person shareholding (lops), it is also not significant in private controlled firms.
} 


\subsubsection{Taking into Account Differences in the Pre- and Post-reform Periods}

Managerial ownership has become more important in recent years and Chinese corporations have been allowed to incentivize their top management with stock and stock options only from January 2006 onwards. Furthermore, firms' ownership structures have changed tremendously following the 2005 split share structure reform in which large part of the non-tradable shares have been converted to tradable shares which have been bought by private shareholders. Consequently, managerial shareholding has increased considerably after 2005 . In particular, it was less than $1 \%$ before 2005 , but has increased to about $8 \%$ by the end of 2010. It is therefore interesting to verify whether managerial ownership has played a more significant effect on firms' leverage decision during the post reform period (2005-2010). To this end, we generate a dummy variable = 1 if year $>2005$, and 0 otherwise and interact it with our proxy for managerial ownership. We include this interaction term in the Equation 1.

The results are reported in column 6 of Table 3 . We can see that, the estimated coefficients on the interaction term (dstmshare*post_reform) is positively and significantly related to leverage ratios in the post reform period, whilst managerial ownership (dstmshare*pre_reform) is found not to have a significant impact on leverage in the pre-reform period. This suggests that the effects of managerial ownership on leverage have only become apparent in the post-reform period.

\section{Conclusions}

In this chapter, we study the relationship between leverage, and both ownership structure and board structure. We find that the ownership structure plays a significant role in determining leverage ratios. More importantly, the study reports a strong positive relationship between managerial shareholding and total leverage, consistent with the incentive alignment hypothesis of Jensen and Meckling (1976). Managerial ownership is positively related to leverage ratios after the 2005 split-share reform, but it does not influence the leverage ratios before the split-share reform. Furthermore, when differentiating listed firms into state and non-state firms, we find that managerial ownership only affects the leverage decisions of private firms. Our empirical results also reveal that state ownership is negatively related to leverage. However, legal person shareholding influence firms' leverage decisions only for state controlled firms. Contrary to our expectation, foreign ownership negatively influences leverage decisions.
Furthermore, the board structure (board size and board composition/proportion of independent directors) does not influence firms' capital structure decisions.

Our research has policy implications. Our findings suggest that recent ownership reforms have been successful in terms of providing incentive to managers through managerial shareholdings to take risky financial choices. Further, our study also suggests that managerial ownership can work as an incentive mechanism in countries like China with unique institutional settings. Therefore, our study recommends that managerial ownership should be further encouraged in state controlled firms so as to provide managers of these firms to take more risk. However, even after the introduction of corporate governance code and the independent director system for Chinese listed corporations like in the Western countries, board of directors, especially independent directors do not seem to influence firms' important decisions like capital structure choices. Thus, our study recommends that a strong and truly independent board structure should be encouraged in the Chinese listed corporations in order to improve effectiveness of their corporate governance.

\section{References}

Abo, J. (2007). Corporate governance and financing decisions of Ghanaian listed firms. Corporate Governance, 7(1), 83-92. https://doi.org/10.1108/14720700710727131

Amihud, Y., \& Lev, B. (1981). Risk reduction as a managerial motive for conglomerate mergers. Bell Journal of Economics, 12, 605-617. https://www.jstor.org/stable/ 3003575

Arellano, M., \& Bover, O. (1995). Another look at the instrumental variable estimation of error-components models. Journal of Econometrics, 68(1), 29-51. https://doi.org/10.1016/0304-4076(94)01642-D

Bhabra, H. S., Liu, T., \& Tirtiroglu, D. (2008). Capital structure choice in a nascent market, evidence from listed firms in China. Financial Management, 37(2), 341-364. https://doi.org/10.1111/j.1755-053X.2008.00015.x

Berger, P. G., Ofek, E., \& Yermack, D. L. (1997). Managerial entrenchment and capital structure decisions. Journal of Finance, 52, 1411-1438. https://doi.org/10.1111/j.1540-6261.1997.tb01115.x

Berle, A. A., \& Means, G. C. (1932). The Modern corporation and private property. New York, NY: Macmillan Publishing Co.

Berkman, H., Cole, R., \& Fu, J. (2002). From State to State: improving corporate governance when the government is a large block holder (Working Paper). Auckland, New Zealand: University of Auckland. 
Blundell, R. W., \& Bond, S. R. (1998). Initial Conditions and moment restrictions in dynamic panel data models. Journal of Econometrics, 87, 115-143. https://doi.org/10.1016/S0304-4076(98)00009-8

Boateng, A., Cai, H., Borgia, D., Gang Bi, X., \& Ngwu, F. N. (2017). The influence of internal corporate governance mechanisms on capital structure decisions of Chinese listed firms. Review of Accounting and Finance, 16(4), 444-461. https://doi.org/10.1108/RAF-12-2015-0193

Booth, L., Aivazian, V., Demirgu, C., Kunt, A., \& Maksimovic, V. (2001). Capital Structures in Developing Countries. Journal of Finance, 56(1), 87-130. https://doi.org/10.1111/0022-1082.00320

Brailsford, T. J., Oliver, B. R., \& Pua, S. L. (2002). On the relation between ownership structure and capital structure. Accounting and Finance, 42(1), 1-26. https://doi.org/10.1111/1467-629X.00001

Brown, P., Beekes, W., \& Verhoeven, P. (2011). Corporate governance, accounting and finance: A review. Accounting and Finance, 51, 96-172. https://doi.org/10.1111/j.1467-629X.2010.00385.x

Chen, J., \& Strange, R. (2005). The Determinants of Capital Structure: evidence from Chinese Listed Companies. Economic Change and Restructuring, 38, 11-35. https://doi.org/10.1007/s10644-005-4521-7

Coffee, J. C. Jr. (1991). Liquidity versus control: The institutional investor as corporate monitor. Columbia Law Review, 91, 1277-1368.

Dixon, R., Guariglia, A., \& Vijayakumaran, R. (2017). Managerial ownership, corporate governance and firms' exporting decisions: Evidence from Chinese listed companies. The European Journal of Finance, 23(7-9), 802-840. https://doi.org/10.1080/1351847X.2015.1025990

Faccio, M, Lang, L. H. P., \& Young, L. (2010). Pyramiding vs leverage in corporate groups: International evidence. Journal of International Business Studies, 41(1), 88-104. https://doi.org/10.1057/jibs.2009.33

Fama, E. (1980). Agency problems and the theory of the firm. Journal of Political Economy, 88(2), 228-307. https://doi.org/10.1086/260866

Fama, E., \& Jensen, M. (1983). Separation of ownership and control. Journal of Law and Economics, 26, 301-325. https://doi.org/10.1086/467037

Florackis, C., \& Ozkan, A. (2009). Managerial incentives and corporate leverage: Evidence from the United Kingdom. Accounting and finance, 49(3), 531-553. https://doi.org/10.1111/j.1467-629X.2009.00296.x

Friend, I., \& Lang, L. (1988). An empirical test of the impact of managerial self-interest on corporate capital structure. Journal of Finance, 43, 271-281. https://doi.org/10.1111/j.1540-6261.1988.tb03938.x
Ghosh, C., Giambona, E., Harding, J. P., \& Sirmans, C. F. (2011). How entrenchment, incentives and governance influence REIT capital structure. The Journal of Real Estate Finance and Economics, 43(1-2), 39-72.

Grossman, S., \& Hart, O. (1982). Corporate financial structure and managerial incentives. In J. McCall (Ed.), The economics of information and uncertainty (pp.107140).

Grier, P., \& Zychowicz, J. (1994). Institutional Investors, Corporate Discipline, and the Role of Debt. Journal of Economics and Business, 46(1), 1-11. https://doi.org/10.1016/0148-6195(94)90017-5

Harris, M., \& Raviv, A. (1991). The Theory of Capital Structure. Journal of Finance, 46(1), 297-355. https://doi.org/10.1111/j.1540-6261.1991.tb03753.x

Huang, G., \& Song, F. M. (2006). The determinants of capital structure, evidence from China. China Economic Review, 17, 14-36. https://doi.org/10.1016/j.chieco.2005.02.007

Jensen, M. (1993). The modern industrial revolution, exit and the failure of internal control systems. Journal of Finance, 48(3), 831-880. https://doi.org/10.1111/j.17456622.2010.00260.x

Jensen, M. (1986). Agency costs of free cash flow, corporate finance and takeovers. American Economic Review, 76(2), 23-39.

Jensen, M. \& Meckling, W. (1976). Theory of the firm, managerial behaviour, agency costs, and capital structure. Journal of Financial Economics, 3(4), 305-360.

Kato, T., \& Long, C. (2006). Executive compensation, firm performance, and corporate governance in China: Evidence from firms listed in the Shanghai and Shenzhen stock exchanges. Economic Development and Cultural Change, 54(4), 945-983. https://doi.org/10.1086/503583

Kato, T., \& Long, C. (2011). Tournaments and managerial incentives in China's listed firms: New evidence. China Economic Review, 22(1), 1-10. https://doi.org/10.1016/j.chieco.2010.08.001

Lemmon, M. L., Roberts, M. R., \& Zender, J. F. (2008). Back to the beginning: persistency and the cross-section of corporate capital structure. The Journal of Finance, LXIII(4). https://doi.org/10.1111/j.1540-6261.2008.01369.x

Lipton, M., \& Lorsch, J. (1992). A modest proposal for improved corporate governance. Business Lawyer, 48(1), 59-77.

Lin H-C, M., \& Bo H. (2012). State-ownership and financial constraints on investment of Chinese-listed firms: new evidence. The European Journal of Finance, 18(6), 497513. https://doi.org/10.1080/1351847X.2011.611523

Mehran, H. (1992). Executive incentive plans, corporate control, and capital structure. Journal of Financial and 
Quantitative $\quad$ Analysis, 27, 539-560. https://doi.org/10.2307/2331139

Pfeffer, J., \& Salancik, G. R. (1978). The external of organisations: A resource dependence perspectives. New York, NY: Harper \& Row.

Qian, Y., Tian, Y., \& Wirjanto, T. S. (2009). Do Chinese publicly listed companies adjust their capital structure toward a target level? China Economic Review, 20, 66276. https://doi.org/10.1016/j.chieco.2009.06.001

Shleifer, A., \& Vishny, R. (1997). A survey of corporate governance. Journal of Finance, 52, 737-775. https://doi.org/10.1111/j.1540-6261.1997.tb04820.x

Stulz, R. (1988). Managerial control of voting rights. Journal of Financial Economics, 20, 25-54. https://doi.org/10.1016/0304-405X(88)90039-6

Stulz, R. (1990). Managerial discretion and optimal financing policies. Journal of Financial Economics, 26, 3-27. https://doi.org/10.1016/0304-405X(90)90011-N

Stulz, R. (2000). Does financial structure matter for economic growth? A Corporate Financial Perspective (Working Paper). Columbus, OH: Ohio State University.

Sun, J., Ding, L., Guo, J. M., \& Li, Y. (2016). Ownership, capital structure and financing decision: evidence from the UK. The British Accounting Review, 48(4), 448-463. https://doi.org/10.1016/j.bar.2015.04.001

Tian, L., \& Estrin, S. (2007). Debt financing, soft budget constraints, and government ownership: evidence from China. Economics of Transition, 15(3), 461-481. https://doi.org/10.1111/j.1468-0351.2007.00292.x

Walder, A. (2011). From control to ownership: China's managerial revolution. Management and Organization Review, 7(1), 19-38. https://doi.org/10.1111/j.17408784.2009.00171.x
Weisbach, M. (1988). Outside directors, monitoring, and the turnover of Chief Executive Officers, An empirical analysis. Journal of Financial Economics, 20, 431-460. https://doi.org/10.1016/0304-405X(88)90053-0

Wen, Y., Rwegasira, K., \& Bilderbeek, J. (2002). Corporate governance and capital structure decisions of the Chinese Listed firms. Corporate Governance: An International Review, 10(2), 75-83. https://doi.org/10.1111/14678683.00271

Wiwattanakantang, Y. (1999). An empirical study on the determinants of the capital structure of Thai firm. Pacificbasin Finance Journal, 7, 371-403. https://doi.org/10.1016/S0927-538X(99)00007-4

Williams, J. (1987). Perquisites, risk and capital structure. Journal of Finance, 42, 29-49. https://doi.org/10.1111/j.1540-6261.1987.tb02548.x

Wintoki, M. B., Linck J. S. \& Netter, J. M. (2012). Endogeneity and the dynamics of internal corporate governance. Journal of Financial Economics, 105(3), 581606. https://doi.org/10.1016/j.jfineco.2012.03.005.

Xu, X., \& Wang, Y. (1999). Ownership structure and corporate governance in Chinese stock companies. China Economic Review, 10, 75-98. https://doi.org/10.1016/S1043-951X(99)00006-1

Yuan, R, Xiao, J \& Zou, H. (2008). Mutual funds' ownership and performance: Evidence from China. Journal of Banking and Finance, 32, 1552-1565. https://doi.org/10.1016/j.jbankfin.2007.08.001

Zou, H., \& Xiao, J. Z. (2006). The Financing Behaviour of Listed Chinese Firms. British Accounting Review, 38, 239258. https://doi.org/10.1016/j.bar.2006.04.008 